\title{
PENGARUH PENGEMBANGAN KARIR DAN MOTIVASI KERJA TERHADAP KINERJA KARYAWAN PT. WISC INDONESIA
}

\author{
Annisa Islamiati ${ }^{1)}$ \\ 1) Mahasiswa Program Studi Manajemen FE UNKRIS \\ Ismail Razak ${ }^{2)}$ \\ ${ }^{2)}$ Dosen Program Studi Manajemen FE UNKRIS \\ Puteri Herlanies Susanto ${ }^{3)}$ \\ 3) Dosen Program Studi Manajemen FE UNKRIS \\ Alamat: Kampus UNKRIS, Jatiwaringin Jakarta Timur \\ Email: ismailrazak.zain@gmail.com
}

\begin{abstract}
The purpose of this study is to analyze the effect of career development and work motivation on the performance of employees of PT. WISC Indonesia. The data used are primary data through questionnaires to employees of PT. WISC Indonesia as respondent. The analytical method used is a simple and multiple linear regression analysis. The results indicated that career development and work motivation had a positive and significant effect on the performance of employees of PT. WISC Indonesia.
\end{abstract}

Keywords: Career development, work motivation and performance of employees.

\section{PENDAHULUAN}

Sumber daya manusia dewasa ini semakin berperan besar bagi kesuksesan suatu perusahaan. Perlu disadari bahwa sumber daya manusia dalam suatu perusahaan dapat memberikan keunggulan bersaing, membuat strategi dan inovasi dalam mencapai tujuan perusahaan. Oleh karena itu, sumber daya manusia merupakan salah satu unsur yang paling penting bagi perusahaan. Dengan demikian, keberhasilan suatu perusahaan dapat dipengaruhi oleh faktor manusia selaku karyawan yang melakukan atau melaksanakan suatu pekerjaan. Dalam suatu perusahaan, kinerja karyawan dapat memberikan dukungan yang baik kepada keunggulan bersaing.

Kinerja karyawan dapat meningkatkan kuantitas dan atau kualitas hasil kerja individu atau sekelompok karyawan dalam melaksanakan tugas pokok dan fungsi yang berpedoman pada norma, standar operasional prosedur, kriteria dan ukuran yang telah ditetapkan atau yang berlaku dalam perusahaan. Kinerja karyawan yang baik adalah keinginan setiap perusahaan. Jika terciptanya kinerja yang baik, maka akan terciptanya hubungan yang harmonis, suasana kerja yang sangat menyenangkan dalam terciptanya tujuan perusahaan.

Peningkatan kinerja karyawan akan membawa kemajuan bagi suatu perusahaan untuk dapat mencapai tujuan perusahaan. Oleh sebab itu, berbagai upaya untuk meningkatkan kinerja karyawan merupakan hal yang paling serius mengingat keberhasilan untuk mencapai tujuan dan kelangsungan hidup suatu perusahaan tergantung pada kinerja karyawan. Semakin banyak karyawan yang memiliki kinerja tinggi, semakin tinggi produktivitas karyawan.

Salah satu upaya untuk meningkatkan kinerja karyawan adalah 
melalui pengembangan karir dan motivasi yang diberikan kepada karyawan. Oleh karena itu dalam penelitian ini, perlu dianalisis pengaruh pengembangan karier dan motivasi terhadap kinerja karyawan.

\section{LANDASAN TEORI}

\section{Kinerja Karyawan}

Istilah kinerja berasal dari kata job performance (prestasi kinerja) atau actual performance (prestasi sesungguhnya) yang dicapai oleh seseorang. Pengertian kinerja (performance) menurut Mangkunegara adalah hasil kerja secara kualitas dan kuantitas yang dicapai oleh seseorang karyawan dalam melaksanakan tugasnya sesuai dengan tanggung jawab yang diberikan kepadanya (Subekhi dan Jauhar, 2012). Menurut Torang (2013), kinerja adalah kuantitas dan atau kualitas hasil kerja individu atau sekelompok didalam perusahaan dalam melaksanakan tugas pokok dan fungsi yang berpedoman pada norma, standar operasional prosedur, kriteria dan ukuran yang telah ditetapkan atau yang berlaku dalam perusahaan. Berdasarkan pengertian kinerja menurut beberapa ahli tersebut, dapat ditarik kesimpulan bahwa kinerja merupakan perwujudan yang dilakukan oleh seorang karyawan dalam meningkatkan hasil kerjanya. Kinerja karyawan merupakan salah satu faktor yang sangat penting dalam upaya meningkatkan kinerja perusahaan.

Menurut Hessel (2007), faktorfaktor yang mempengaruhi kinerja perusahaan adalah budaya perusahaan, kompensasi, kepemimpinan, motivasi kerja, kedisiplinan, lingkungan kerja dan komitmen perusahaan. Sementara itu, Mangkunegara (2011) mengemukakan bahwa faktor yang mempengaruhi pencapaian kinerja adalah faktor kemampuan (secara psikologis terdiri atas kemampuan potensi dan kemampuan realitas, yaitu pengetahuan dan ketrampilan) dan faktor motivasi. Menurut Werther dan Davis (1996) dalam Suwatno dan Priansa (2011) penilaian kinerja mempunyai beberapa tujuan dan manfaat bagi perusahaan dan karyawan yang dinilai, antara lain: 1) Performance improvement (memungkinkan karyawan dan manajer untuk mengambil tindakan yang berhubungan dengan peningkatan kinerja), 2) Compensation adjustment (membantu dalam pengambil keputusan untuk menentukan siapa saja yang berhak menerima kenaikan gaji atau sebaliknya), 3) Placement decision (menentukan promosi, transfer, dan demotion), 4) Training and development needs (mengevaluasi kebutuhan pelatihan dan pengembangan bagi karyawan agar kinerja mereka lebih optimal), 5) Carrer planning and development (memandu untuk menentukan jenis karier dan potensi karier yang dapat dicapai), 6) Staffing process deficiencies (mempengaruhi prosedur perekrutan karyawan), dan 7) Informational inaccuracies and job-design errors (membantu menjelaskan apa saja kesalahan yang telah terjadi dalam manajemen sumber daya manusia terutama dibidang informasi, analisis pekerjaan, dan rancangan pekerjaan).

Mas'ud (2004) mengungkapkan bahwa kinerja karyawan dapat diukur melalui indikator sebagai berikut: 1). Kualitas; Kualitas kerja diukur dari persepsi karyawan terhadap kualitas pekerjaan yang dihasilkan serta kesempurnaan tugas terhadap keterampilan dan kemampuan karyawan. 2). Kuantitas; Kuantitas kerja merupakan jumlah yang dihasilkan dinyatakan dalam istilah seperti jumlah unit, jumlah siklus aktivitas yang diselesaikan. 3). Ketepatan waktu; Ketepatan waktu merupakan tingkat aktivitas diselesaikan pada awal waktu yang dinyatakan, dilihat dari sudut koordinasi dengan hasil output serta memaksimalkan waktu yang tersedia 
untuk aktivitas lain. 4). Efektivitas; Efektivitas merupakan tingkat penggunaan sumber daya perusahaan (tenaga, uang, teknologi, bahan baku) dimaksimalkan dengan maksud menaikkan hasil dari setiap unit dalam penggunaan sumber daya. 5). Kemandirian; Kemandirian merupakan tingkat seorang karyawan yang nantinya akan dapat menjalankan fungsi kerjanya, dan 6) Komitmen kerja; Komitmen kerja merupakan suatu tingkat dimana karyawan mempunyai komitmen kerja dengan instansi dan tanggung jawab karyawan terhadap kantor".

\section{Pengembangan Karir}

Menurut Rivai dan Sagala (2009) pengembangan karir adalah proses peningkatan kemapuan kerja individu yang dicapai dalam rangka mencapai karir yang diinginkan, sedangkan menurut Handoko (2012), pengembangan karir adalah peningkatan pribadi yang dapat di lakukan seseorang untuk mencapai suatu rencana karir yang telah direncanakan (dalam Megita (2014). Dapat ditarik kesimpulan dari pendapat para ahli, bahwa pengembangan karir merupakan rangkaian suatu kegiatan yang dilakukan seorang karyawan untuk meningkatkan kemampuan kerja dalam merencanakan karir dimasa sekarang dan masa yang akan datang.

Bentuk-bentuk pengembangan karir itu sendiri tergantung pada jalur karir yang telah direncanakan oleh masingmasing perusahaan. Bagaimana suatu perusahaan menentukan jalur karir bagi setiap karyawan tergantung pada kebutuhan dan situasi suatu perusahaan itu sendiri, namun umumnya sering dilalukan melalui mutasi, pelatihan, dan promosi.

Pada umumnya tujuan dari seluruh program pengembangan karir adalah untuk menyesuaikan antara kebutuhan dan tujuan karyawan dengan kesempatan karir yang tersedia diperusahaan saat ini dan di masa mendatang. Adapun tujuan pengembangan karir yang dikemukakan oleh Dubrin (1982) adalah sebagai berikut: 1). Membantu dalam pencapaian tujuan individu dan perusahaan. Pengembangan karir membantu pencapaian tujuan perusahaan dan tujuan individu. Seorang karyawan yang sukses dengan prestasi kerja sangat baik kemudian menduduki posisi jabatan yang lebih tinggi, hal ini berarti tujuan perusahaan dan tujuan individu tercapai. 2). Menunjukkan hubungan kesejahteraan karyawan. Perusahaan merencanakan karir karyawan dengan meningkatkan kesejahteraannya agar karyawan lebih tinggi loyalitasnya. 3). Membantu karyawan menyadari kemampuan potensi mereka. Pengembangan karir membantu menyadarkan karyawan akan kemampuannya untuk menduduki suatu jabatan tertentu sesuai dengan potensi dan keahliannya. 4). Memperkuat hubungan antara karyawan dan perusahaan. Pengembangan karir akan memperkuat hubungan dan sikap karyawan terhadap perusahaannya. 5). Membuktikan tanggung jawab sosial. Pengembangan karir suatu cara menciptakan iklim kerja yang positif dan karyawan menjadi lebih bermental sehat. 6). Membantu memperkuat pelaksanaan program-program perusahaan. Pengembangan karir membantu programprogram perusahaan lainnya agar tujuan perusahaan tercapai. 7). Mengurangi turnover dan biaya kepegawaian. Pengembangan karir dapat menjadikan turnover rendah dan begitu pula biaya kepegawaian menjadi lebih efektif. 8). Mengurangi keusangan profesi dan manajerial. Pengembangan karir dapat menghindarkan dari keusangan dan kebosanan profesi dan manajerial. 9). Menggiatkan analisis dari keseluruhan karyawan. Pengembangan karir dimaksudkan mengintegrasikan perencanaan kerja dan kepegawaian. 10). Menggiatkan suatu pemikiran 
(pandangan) jarak waktu yang panjang. Pengembangan karir berhubungan dengan jarak waktu yang panjang (dalam Mangkunegara, 2011).

Manfaat pengembangan karir secara umum menurut Kadarisman (2012) adalah; 1). Mengembangkan prestasi karyawan. 2). Mencegah terjadinya karyawan yang minta berhenti untuk pindah kerja, dengan cara meningkatkan loyalitas karyawan. 3). Sebagai wahana untuk memotivasi karyawan agar dapat mengembangkan bakat dan kemampuannya. 4). Mengurangi subyektivitas dalam promosi. 5). Memberikan kepastian hari depan. 6). Sebagai usaha untuk mendukung perusahaan memperoleh tenaga yang cakap dan trampil dalam melaksanakan tugas.

Indikator pengembangan karir menurut Handoko (2012), adalah 1). Latar belakang pendidikan merupakan salah satu syarat untuk duduk di sebuah jabatan. Pendidikan adalah suatu kegiatan untuk meningkatkan penguasaan teori dan keterampilan untuk memutuskan persoalan-persoalan yang menyangkut pekerjaan guna mencapai tujuan. Indikator latar belakang pendidikan adalah jenjang pendidikan. 2). Pelatihan merupakan proses mengajarkan pengetahuan dan keahlian tertentu serta sikap agar karyawan semakin terampil dan mampu melaksanakan tanggung jawab dengan semakin baik dan pada akhirnya pelatihan tersebut dapat menunjang tercapainya tujuan perusahaan. Indikator pelatihan adalah frekuensi pelatihan. 3). Pengalaman kerja adalah tingkat penguasaan pengetahuan serta keterampilan seseorang yang dapat di ukur dari masa kerja seseorang. Indikator pengalaman kerja adalah lama kerja dalam Megita (2014).

\section{Motivasi Kerja}

Motivasi berasal dari kata latin (movere) yang berarti dorongan, daya penggerak atau kekuatan yang menyebabkan suatu tindakan atau perbuatan (dalam Suwanto dan Priansa, 2011). Motivasi mempersoalkan cara mengarahkan daya dan potensi bawahan agar mau bekerja secara produktif dalam mencapai dan mewujudkan tujuan yang telah ditentukan. Menurut Hasibuan, motivasi adalah suatu perangsang keinginan daya penggerak kemauan bekerja seseorang, setiap motif mempunyai tujuan tertentu yang ingin dicapai (dalam Sunyoto, 2012), sedangkan menurut Wibowo (2010), motivasi merupakan dorongan terhadap serangkaian proses perilaku manusia pada pencapaian tujuan. Berdasarkan pendapat para ahli tersebut dapat disimpulkan bahwa motivasi kerja merupakan dorongan terhadap rangkaian proses perilaku karyawan pada pencapaian tujuan.

Tujuan motivasi menurut Hasibuan (2011) adalah: 1). Meningkatkan moral dan kepuasan kerja karyawan. 2). Meningkatkan produktivitas kerja karyawan 3). Mempertahankan kestabilan karyawan perusahaan. 4). Meningkatkan kedisiplinan karyawan. 5). Mengefektifkan pengadaan karyawan. 6). Menciptakan suasana dan hubungan kerja yang baik. 7). Meningkatkan loyalitas, kreativitas, dan partisipasi karyawan. 8). Mempertinggi rasa tanggung jawab karyawan terhadap tugas-tugasnya. $\quad 9$ ). Meningkatkan kesejahteraan karyawan. 10). Meningkatkan efisiensi penggunaan alat-alat dan bahan baku. 
Indikator yang digunakan untuk mengukur motivasi karyawan menurut Rivai (2004) antara lain, yaitu: 1). Rasa aman dalam bekerja. 2). Mendapatkan gaji yang adil dan kompetitif. 3). Kondisi lingkungan yang menyenangkan. 4). Penghargaan terhadap prestasi kerja. 5). Perlakuan yang adil dari pimpinan atau perusahaan.

\section{Hipotesis}

1. Pengembangan karier berpengaruh positif dan signifikan terhadap kinerja karyawan.

2. Motivasi kerja berpengaruh positif dan signifikan terhadap kinerja karyawan.

3. Pengembangan karier dan motivasi berpengaruh positif dan signifikan terhadap kinerja karyawan.

\section{METODE PENELITIAN}

Tujuan penelitian ini adalah untuk menganalisis hubungan kausalitas antara pengembangan karir dan motivasi kerja dengan kinerja karyawan. Data yang digunakan adalah data primer dengan menyebar kuesioner kepada karyawan PT. WISC Indonesia. Metode analisis data yang digunakan dalam penelitian ini adalah analisis deskriptif, analisis regresi linear sederhana dan analisis regresi linear berganda. Populasi dalam penelitian ini adalah seluruh karyawan
PT. WISC Indonesia yang berjumlah 50 karyawan terdiri dari 25 karyawan berstatus tetap dan 25 karyawan berstatus tenaga kontrak. Teknik pengambilan sampel dalam penelitian ini menggunakan teknik sampling jenuh (sensus), yaitu teknik pengumpulan sampel bila semua anggota populasi digunakan sebagai sampel. Hal ini dilakukan karena jumlah populasi relatif tidak terlalu banyak, sehingga jumlah sampel ditentukan sebanyak 50 karyawan PT. WISC Indonesia sebagai responden.

\section{HASIL PENELITIAN DAN PEMBAHASAN}

\section{Hasil Penelitian}

\section{Uji Validitas dan Uji Reliabilitas}

Dari perhitungan koefisien korelasi, skor setiap butir pernyataan dari 50 responden tentang pengembangan karier berjumlah 9 pernyataan, motivasi kerja sebanyak 10 pernyataan, dan kinerja sebanyak 10 pernyataan. Hasil pengujian validitas menunjukkan bahwa seluruh butir pernyataan dinyatakan valid, karena $\mathrm{r}$-hitung lebih besar dari 0,3 ( $\mathrm{r}_{\text {-kritis}}$ ), sedangkan hasil pengujian reliabilitas menunjukkan bahwa seluruh variabel yang diteliti dinyatakan reliabel, karena mempunyai cronbach's alpha di atas 0,6.

\section{Hasil Uji Hipotesis}

\section{Hipotesis Pertama}

Tabel 1: Pengaruh Pengembangan Karir terhadap Kinerja Karyawan

\begin{tabular}{|c|c|c|c|c|c|}
\hline \multirow[b]{2}{*}{ Variabel } & \multicolumn{5}{|c|}{ Parameter } \\
\hline & $\mathbf{R}$ & $\begin{array}{c}\mathbf{R} \\
\text { Square }\end{array}$ & Konstanta & $\begin{array}{c}\text { Koefisien } \\
\text { Regresi }\end{array}$ & Sig \\
\hline Peng_Karir & 0,813 & 0,661 & 15,010 & 0,759 & 0,000 \\
\hline \multicolumn{6}{|c|}{ Pengujian Signifikan } \\
\hline \multicolumn{6}{|c|}{$\mathrm{t}$ hitung $>\mathrm{t}$ tabel $=9,681>2,011$} \\
\hline
\end{tabular}


Nilai koefisien determinasi $\left(\mathrm{R}^{2}\right)$ sebesar 0.661 , artinya pengembangan karir memberikan kontribusi sebesar $66,1 \%$ kepada kinerja karyawan PT. WISC Indonesia, sedangkan sisanya sebesar 33,9\% disumbangkan faktor lain, seperti motivasi dan sebagainya. Pengembangan karir berpengaruh positif dan signifikan pada tingkat nyata $99 \%$ terhadap kinerja karyawan PT. WISC
Indonesia. Koefisien pengembangan karir bertanda positif, artinya jika ada peningkatan pengembangan karir, maka kinerja PT. WISC Indonesia akan meningkat atau sebaliknya. Dengan demikian, hipotesis pertama teruji dan hasil penelitian membuktikan bahwa terdapat hubungan kausalitas antara pengembangan karier dengan kinerja karyawan

\section{Hipotesis Kedua}

Tabel 2: Pengaruh Motivasi Kerja Terhadap Kinerja Karyawan

\begin{tabular}{lccccc}
\hline \multirow{2}{*}{ Variabel } & $\mathbf{R}$ & $\begin{array}{c}\mathbf{R} \\
\text { Square }\end{array}$ & Konstanta & $\begin{array}{c}\text { Koefisien } \\
\text { Regresi }\end{array}$ & Sig \\
\cline { 2 - 6 } & 0,743 & 0,552 & 14,012 & 0,674 & 0,000 \\
\hline Motivasi & 0,745 & & \\
\hline Pengujian Signifikan & & & \\
\hline t hitung $>$ t tabel $=9,681>2,011$ & & \\
Sumber: data diolah 2019
\end{tabular}

Nilai koefisien determinasi $\left(\mathrm{R}^{2}\right)$ sebesar 0.552, artinya motivasi kerja memberikan kontribusi kepada kinerja karyawan PT. WISC Indonesia sebesar $55,2 \%$, sedangkan sisanya sebesar $44,8 \%$ disumbangkan faktor lain, seperti pengembangan karier dan sebagainya. Motivasi kerja berpengaruh positif dan signifikan pada tingkat nyata $99 \%$ terhadap kinerja karyawan PT. WISC
Indonesia. Koefisien motivasi kerja bertanda positif, artinya jika ada peningkatan motivasi kerja, maka kinerja karyawan PT. WISC Indonesia akan meningkat atau sebaliknya. Dengan demikian, hipotesis kedua teruji dan hasil penelitian membuktikan bahwa terdapat hubungan kausalitas antara motivasi kerja dengan kinerja karyawan.

\section{Hipotesis Ketiga}

Tabel 3: Pengaruh Pengembangan Karir dan Motivasi Kerja Terhadap Kinerja Karyawan

\begin{tabular}{lccccc}
\hline \multirow{2}{*}{ Variabel } & Mult. R & $\begin{array}{c}\text { R } \\
\text { Square }\end{array}$ & Konstanta & $\begin{array}{c}\text { Koefisien } \\
\text { Regresi }\end{array}$ & Sig. \\
\hline $\begin{array}{llcccc}\text { Peng_Karir } \\
\text { Motivasi }\end{array}$ & 0,839 & 0,704 & 11,072 & 0,544 & 0,000 \\
\hline Pengujian Signifikan & & & \\
\hline F hitung > F tabel = 55,906 > 3,195 & & 0,002 \\
\hline Sumber: data diolah 2019
\end{tabular}


Nilai F hitung sebesar 55,906, artinya secara bersama-sama pengembangan karir dan motivasi kerja berpengaruh signifikan pada tingkat nyata 99\% terhadap kinerja karyawan PT. WISC Indonesia. Nilai koefisien determinasi $\left(\mathrm{R}^{2}\right)$ sebesar 0.704 , artinya pengembangan karir dan motivasi kerja memberikan kontribusi sebesar 70,4\% kepada kinerja karyawan PT. WISC Indonesia, sedangkan sisanya sebesar $29,6 \%$ disumbangkan faktor lain yang tidak dibahas dalam penelitian ini, seperti kepuasan kerja dan sebagainya.

Pengembangan karir dan motivasi kerja berpengaruh positif dan signifikan terhadap kinerja karyawan PT. WISC Indonesia, pada tingkat nyata $99 \%$. Koefisien pengembangan karir bertanda positif, artinya jika ada peningkatan pengembangan karir, maka kinerja karyawan PT. WISC Indonesia akan meningkat atau sebaliknya dengan asumsi motivasi kerja tidak berubah. Koefisien motivasi kerja bertanda positif, artinya jika ada peningkatan motivasi kerja, maka kinerja karyawan PT. WISC Indonesia akan meningkat atau sebaliknya, dengan asumsi pengembangan karir tidak berubah.

\section{Pembahasan}

\section{Pengaruh Pengembangan Karir Terhadap Kinerja Karyawan}

Hasil penelitian menunjukkan bahwa pengembangan karir mendukung peningkatan kinerja karyawan PT. WISC Indonesia. Hal ini menunjukkan bahwa semakin baik pengembangan karir yang diterapkan dalam perusahaan akan dapat meningkatkan kinerja karyawan. Tingkat pendidikan, frekuensi pelatihan dan lamanya masa kerja merupakan aspekaspek pribadi dari karyawan yang menjadi dasar untuk pengembangan karir, sehingga kinerja karyawan meningkat. Hasil penelitian ini sesuai dengan hasil penelitian yang dilakukan oleh Rosalina, (2016), dan Nurdin, et, al (2018) yang membuktikan bahwa pengembangan karir berpengaruh terhadap kinerja karyawan.

\section{Pengaruh Motivasi Kerja terhadap Kinerja Karyawan}

Hasil penelitian menunjukkan bahwa motivasi kerja mendukung peningkatan kinerja karyawan PT. WISC Indonesia. Hal ini dikarenakan bahwa adanya rasa aman karyawan dalam bekerja, gaji yang diterima sesuai dengan peraturan dan kompetitif, kondisi lingkungan kerja yang nyaman, adanya penghargaan atas prestasi kerja dan perlakuan yang adil dari pimpinan pada karyawan, sehingga kinerja karyawan meningkat. Hasil penelitian ini sesuai dengan hasil penelitian yang dilakukan oleh Anggara, et, al (2016) dan Kurniawan, et, al (2018) yang membuktikan bahwa motivasi kerja berpengaruh terhadap kinerja karyawan.

\section{Pengaruh Pengembangan Karir dan Motivasi kerja terhadap Kinerja Karyawan}

Hasil penelitian menunjukkan bahwa pengembangan karir dan motivasi kerja mendukung peningkatan kinerja karyawan PT. WISC Indonesia. Hasil penelitian ini sesuai dengan hasil penelitian yang dilakukan oleh Rosalina, (2016), Nurdin, et, al (2018), ), Anggara, et, al (2016) dan Kurniawan, et, al (2018) yang membuktikan bahwa pengembangan karir dan motivasi kerja berpengaruh terhadap kinerja karyawan.

\section{KESIMPULAN DAN SARAN}

\section{Kesimpulan}

1. Berdasarkan hasil analisis deskriptif menunjukkan bahwa indikator memberikan kontribusi terbesar dalam pengembangan karir adalah pendidikan, sedangkan indikator yang 
memberikan kontribusi terbesar dalam motivasi kerja adalah rasa aman dalam bekerja. Indikator yang memberikan kontribusi terbesar dalam kinerja karyawan adalah kualitas kerja.

2. Pengembangan karir dan motivasi mendukung peningkatan kinerja karyawan PT. WISC Indonesia baik secara sendiri-sendiri maupun secara bersama-sama.

\section{Saran}

Pengembangan karier dan motivasi kerja sebagai faktor yang mendukung peningkatan kinerja karyawan perlu dilakukan perbaikan secara berkesinambungan secara terus menerus. Perlu dipertimbangkan untuk dilakukan penelitian berikutnya dengan mempertimbangkan motivasi kerja sebagai variabel yang memediasi (intervening variable) pengembangan karier terhadap kinerja karyawan.

\section{DAFTAR PUSTAKA}

Anggara, Arief Bhakti,. Lelly H.S Sri Wahyu., dan M. Syaharudin. 2016. Pengaruh Motivasi dan Pengembangan Karir terhadap Kinerja Karyawan pada Best Finance Indonesia Kabupaten Jember. Artikel Ilmiah Mahasiswa.

Dubrin, Andrew J. 1982. The Complete Ideal's Guides: Leadership, Edisi Kedua. Jakarta. Prenada.

Griffin, Ricky W; Ebert, Ronald J. 2007. Manajemen Bisnis. Jilid 1. Edisi Kedelapan. Jakarta. Erlangga.

Handoko, T. Hani. 2012. Manajemen Personalia dan Sumber Daya Manusia. Yogyakarta. BPFE.

Hasibuan, Malayu S.P. 2011. Manajemen Sumber Daya Manusia. Edisi Revisi. Jakarta. Penerbit Bumi Aksara.
Koontz, Harold, Cyrill O'Donnell, dan Heinz Weichrich, 1986, Essential of Management, Fourth Edition, New York - USA. McGraw-Hill Book.

Kadarisman, M. 2012. Manajemen Pengembangan Sumber Daya Manusia. Jakarta. PT. Raja Grafindo Persada.

Kurniawan, Ade Dharma,. Rivai, Abdul, dan Suharto. 2018. Pengaruh Pengembangan Karir dan Motivasi terhadap Kinerja Karyawan melalui Komitmen Perusahaan pada Bagian Pengembangan Institusi Pendidikan Daniyah Pondok Pesantren Kantor Kementerian Agama Jakarta Selatan. International Journal of Business And Applied Social Science (IJBASS), Vol: 4, Vol: 4, ISSUE: 2, E-ISSN: 2469-6501. Hal: 17-33.

Mangkunegara, A.P. 2011. Manajemen Sumber Daya Manusia Perusahaan. Bandung. Remaja Rosdakarya.

Mas'ud, Fuad. 2004. Manajemen Sumber Daya Manusia. Semarang. Badan Penerbit Universitas Diponegoro.

Megita, Candra. 2016. Pengaruh Pengembangan Karir terhadap Kinerja Karyawan. Jurnal Vol.4, No.1, diaskses 25 Oktober 2016.

Nurdin, Nela Resta dan Lapiran, S.L.H.V. Joyce. 2018. Pengaruh Pengembangan Karir dan Motivasi Kerja terhadap Kinerja pada PT Sumber Alfaria Trijaya, Tbk Cabang Manado. Jurnal EMBA, Vol. 6 No. 4 September 2018, Hal. 3773-3782, ISSN : 2303-1174.

Prawirosentono, Suyadi. 2002. Manajemen Sumber Daya Manusia: Kebijakan Kinerja Karyawan. Edisi 1. Cetakan Kedelapan. Yogyakarta. BPFE.

Rivai, Veitzhal. 2004. Manajemen Sumber Daya Manusia untuk 
Perusahaan. Jakarta. PT. Ganudra Pustaka Utama.

Rivai, Veitzhal dan Sagala, Ella Jauvani. 2009. Manajemen Sumber Daya Manusia Untuk Perusahaan: dari Teori ke Praktek. Jakarta. Raja Grafindo Persada.

Rosalina, Lamsiska. 2016. Pengaruh Pengembangan Karir dan Motivasi terhadap Kinerja Karyawan pada Verena Multi Finance Tbk, Cabang Pekanbaru. JOM FISIP. Vo. 3 No. 2 - Oktober 2016, hal: 1 -11 .

Subekhi, Akhmad dan Jauhar, Mohammad. 2012. Pengantar Manajemen Sumber Daya Manusia. Jakarta. Prestasi Pustakaraya.
Sugiyono. 2016. Statikstika Untuk Penelitian. Bandung. Penerbit Alfabeta.

Sunyoto, Danang. 2012. Manajemen Sumber Daya Manusia. Yogyakarta. Nuba Medika.

Suwatno dan Priansa, Donni Juni. 2011. Manajemen Sumber Daya Manusia dalam Perusahaan Publik dan Bisnis. Bandung. Alfabeta.

Tangkilisan, Hessel Nogi. 2005. Manajemen Publik. Gramedia Widia. Jakarta.

Torang, Syamsir. 2013. Perusahaan dan Manajemen. Bandung. Alfabeta.

Werther, William B. dan Keith Davis, 1996. Manajemen Personalia dan Sumber Daya Manusia. Bandung. Erlangga.

Wibowo. 2010. Manajemen Kinerja. Jakarta. Rajawali Pers. 